\title{
Behavioral Issues for Sustainable Investment Decision-Making: A Literature Review
}

\author{
Andrea Tomo ${ }^{1,2} \&$ Giovanni Landi ${ }^{1}$ \\ ${ }^{1}$ Department of Economics, Management and Institutions, University of Naples "Federico II", Naples, Italy \\ ${ }^{2}$ Institute for Research on Innovation and Services for Development, Italian National Research Council, Naples, \\ Italy \\ Correspondence: Andrea Tomo, Department of Economics, Management and Institutions, University of Naples \\ “Federico II", Complesso Universitario Monte S. Angelo, Via Cinthia, 80126 Naples, Italy. Tel: 390-8167-9845. \\ E-mail: andrea.tomo@unina.it
}

Received: October 17, 2016

Accepted: November 9, $2016 \quad$ Online Published: December 26, 2016

doi:10.5539/ijbm.v12n1p1

URL: http://dx.doi.org/10.5539/ijbm.v12n1p1

\begin{abstract}
The aim of this work is to understand the role of the Environmental, Social and Governance (ESG) paradigm in the corporate assessment by investors and the use of this paradigm as guide for managerial decision-making process by corporations. A review of the international literature is provided using five different couples of keywords on Thomson Reuters ISI Web of Knowledge research engine. The literature production increased only after the 2007 crisis and the median year of the results is 2011, thus highlighting just a recent attention to themes as ethics and corporate social responsibility. Main limitations are related to the classic limitations of literature reviews, as the choice of number and type of keywords and journals, the resulting selection of studies, the choice of relevant outcomes and the interpretation, generalization and application of results. The study provides both theoretical and practical implications: a complete review of contributions on the theme is provided; then, some insights in investors and corporations behaviors through the ESG lens, thus suggesting a more ethical and responsible behavior in investment decision-making processes.
\end{abstract}

Keywords: investment behavior, impact investing, corporate social responsibility, sustainable asset management, environmental, social and governance, corporate strategy, financial performance

\section{Introduction}

Looking at the main causes of financial crises, it is necessary to understand what the real root of the problem is. High risk, short term investments, moral hazard, and human ambitions often drive human beings to assume a speculative behavior when investing to get richer in the shortest amount of time (Petrick, 2011).

Over the twentieth century scant attention has been paid to themes such as ethics, sustainability, and responsible investments, both by academic theories and financial practitioners, and the results are under our eyes (e.g., Stachowicz-Stanusch \& Mangia, 2016).

The last twenty years, in fact, have been abundant in numerous examples of corruption scandals and unethical behaviors in modern organizations and instances of management misconduct that have eroded public faith (such as Enron, WorldCom, Tyco, Adelphia, Arthur Andersen, \& Parmalat). Their unawareness of the risk associated with management misconduct also resulted in the erosion of public trust to their organizations and in the collapse of profitable corporations. Hence, underestimation of unethical behaviors may lead to severe consequences (Stachowicz-Stanusch \& Mangia, 2016).

Only in the aftermath of 2007 crisis, literature started adopting a more ethical and behavioral oriented approach to finance (Baker \& Ricciardi, 2014). The recent awakening of focused attention to themes such as ethics, sustainability, and responsible investments has demonstrated the need for a deeper understanding of these themes both from academics and practitioners. Some authors, for example, contend that only through a new ethical paradigm, and by challenging the anthropocentric capitalist society, humanity can evolve in a sustainable way (Devall \& Sessions, 2001; Soskolne, 2007).

The research focuses on the role of the Environmental, Social and Governance (ESG) paradigm in the evaluation of responsible corporations. The adoption of this paradigm is analyzed both from investors and corporate side, to 
verify the impact of ESG paradigm on investors' behavior and managerial decision-making process for investing. On this basis, the paper aims to understand how a corporate ESG-based behavior influences investment decision-making process.

The paper is structured as follows: the following section presents the theoretical background on investors' behavior and organizational issues related to ethics; the third section describes the methodology used for the literature review; the fourth section presents results and discussion. Finally, some implications both for academic researchers and financial practitioners on investment decision-making process are provided.

\section{Theoretical Background}

\subsection{Investors' Behavior and Decision-Making Processes in Investing}

The old oriented approach to the profit maximization is clear in the belief that investors have often had in assuming that all of the information was available to invest in a rational way. For example, Modern Portfolio Theory (Markovitz, 1952) evidences several limits related to the concepts of rational decisions, sophistication, well informed investors, and complete information available.

On this aspect, an interesting concept is the illusion of skills introduced by Kahneman (2011). According to this concept, financial investors are characterized by the illusion of being experts, and this influences their way of thinking and, in turn, their decision-making process (Kahneman, 2011). This illusion is enhanced by the context in which they have studied and grown professionally, and it leads financial actors to think they always have all information to predict how investments will evolve in the future (Kahneman, 2011). Indeed, Kahneman (2011) underlines how financial experts make reasonable hypotheses in a highly uncertain situation, by the fact that previsions are per definition uncertain. Short-term tendencies, as well as behaviors, can be more easily predicted than long-term horizons by considering previous behaviors and results, but the fact that both tests and real world situations are characterized by specific context factors that make each situation different should be taken into account (Kahneman, 2011). Furthermore, as evidenced by Simon (1955), Akerlof (1970), people do not make rational decisions due to bounded rationality and information asymmetry. Acquisti and Grossklags (2005), highlight, in fact, that often people are also likely to trade off long-term privacy for short-term benefits.

In financial markets information asymmetry is often amplified considering, on one side, the lack of competence and knowledge by investors on financial matters and, on the other side, the lack of documents disclosure by firms, banks and rating agencies (Barlevy and Veronesi, 2000; Frankel and Li, 2004). In addition, investors' behaviors and their decision-making processes regarding investments should also be considered and analyzed. Investor behavior is based on cognitive factors (mental processes) and affective issues (emotions) that financial actors reveal during their financial planning and investment management processes (Kahneman, 2011). In brief, investors' decision-making processes are influenced by past events, personal beliefs, and personal preferences (Baker and Ricciardi, 2014).

\subsection{Organizational Models for Social and responsible Management}

The recent growing interest to CSR has raised questions on issues as research, training, comprehension of concepts and implementation of CSR practices (Hopkins, 2004). One of the main issues, for instance, regards the organizational design and practices, to better align the organization with the dynamic demands of the business and social environment by identifying and managing stakeholder expectations (Maon et al., 2009). Maon et al. (2009), based on a review of literature concerning the implementation of CSR practices, suggest a framework for designing and implementing CSR in 9 steps:

1. Raising CSR awareness inside the organization;

2. Assessing corporate purpose in a societal context;

3. Establishing a vision and a working definition for CSR;

4. Assessing CSR status;

5. Developing a CSR integrated strategic plan and embedding CSR in organizational strategy;

6. Implementing CSR-integrated strategic plan and implementing organizational initiatives and strategies linked to CSR;

7. Communicating about CSR commitments and performance;

8. Evaluating CSR integrated strategies and communication and evaluating, verifying, and reporting on CSR progress; 
9. Institutionalizing CSR and anchoring changes into organizational systems, as well as corporate culture and values.

This procedure should always involve stakeholders in a constructive dialogue for improving internal CSR practices.

Other organizational issues may be related to the organizational design: e.g., should the CSR function be a part of a specific department, a special committee or internal to the executive board?

The Corporate Excellence - Centre for Reputation Leadership (2011) highlights how different companies have opted for different solutions: for example, some companies, following the assumption of CSR as a communication strategy, related it to the Communication Department due to external need to manage stakeholders, image and reputation. Other companies opted for the inclusion within the Human Resource Department, in order to manage issues related to the Talent Management, Internal Reputation or Labor Relations. A third possible solution, might be the adoption of an integrator manager (an Ethics Officer or responsible), responsible to follow each department in developing CSR vision and mission.

Considering the premises on which CSR lays, we should conclude that CSR should be adopted as an overall strategy: the choice of a specific manager seems to be more coherent with the aim of CSR. In fact, a specific manager might result more focused to drive the company in integrating a socially responsible behavior. An effective Ethics manager like all good managers, need to have a strategic vision for the organization's ethics and compliance program. Part of this vision needs to be a holistic understanding of how ethics and compliance fits with, supports and operates alongside other parts of the business. For example, ethics and compliance need to be embedded in the company's strategic orientation for new hires, embedded in how employees are evaluated and rewarded, embedded in internal and external communication and ultimately a permanent part of the corporation's identity. In other words, this strategic approach allows knowing where to devote energies and capital resources to make the biggest impact on organizational behavior. This behavior should not be approached in a top-down manner, but it should involve all the organizational levels, thus becoming a relevant part of shared organizational culture, values and norms (Maignan et al., 2005; Panapanaan et al., 2003).

\section{Methodology}

The hypothesis taken into account for the following literature review is that social and responsible investor behavior, and the inclusion of ESG parameters in investment evaluations, has a positive impact on corporate financial performances. Thus, to analyze the relevance of studies matching the highlighted themes above, international literature was reviewed using a systematic approach through the Thomson Reuters ISI Web of Knowledge research engine. The time span was set from 1990 to 2016 in order to take into account literature produced over the twenty years observed.

The review process was structured into five steps (Khan et al., 2003):

1. Framing questions for a review, by establishing useful keywords;

2. Eliminating duplicates and identifying relevant studies by selecting titles and abstracts;

3. Assessing the quality of studies, by analyzing full papers;

4. Summarizing the evidence; and

5. Interpreting the findings.

In the first step, five keywords (or couples of keywords) were used in the topic field: sustainable finance, corporate social performance AND impact investing, market efficiency AND abnormal return, moral hazard AND information asymmetry, and financial performance AND ESG rating. This step produced 1.485 articles; then results have been filtered per journal, on the basis of their coherence to the aim of this study (17 journals selected, as listed below in Table 1). At the end of the first step, results included 153 articles.

Table 1. Journals selected

\footnotetext{
Annals Of Economics And Finance

Business \& Society

Business Horizons

Corporate Governance And Business Ethics

Corporate Social Responsibility And Environmental Management

European Journal Of Finance
} 


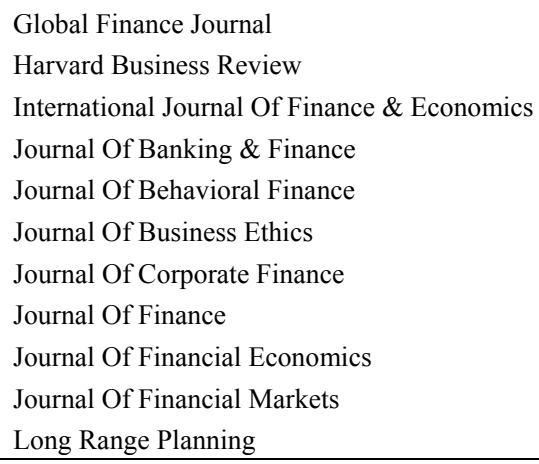

The second step consisted in eliminating duplicates and in selecting articles using several keywords (impact, rating, ethic, social, governance, environment, sustainable, responsible, responsibility, performance) within titles and abstracts. After this step, 18 articles resulted.

In the third step articles were analyzed by full-text: 8 articles after the full text analysis were excluded, thus providing us a final set of 10 articles.

Figure 1 shows the review process from step 1 through step 3.

Step 1

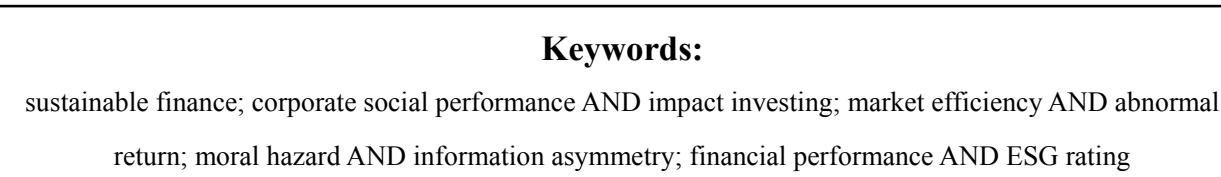

Step 2

Step 3

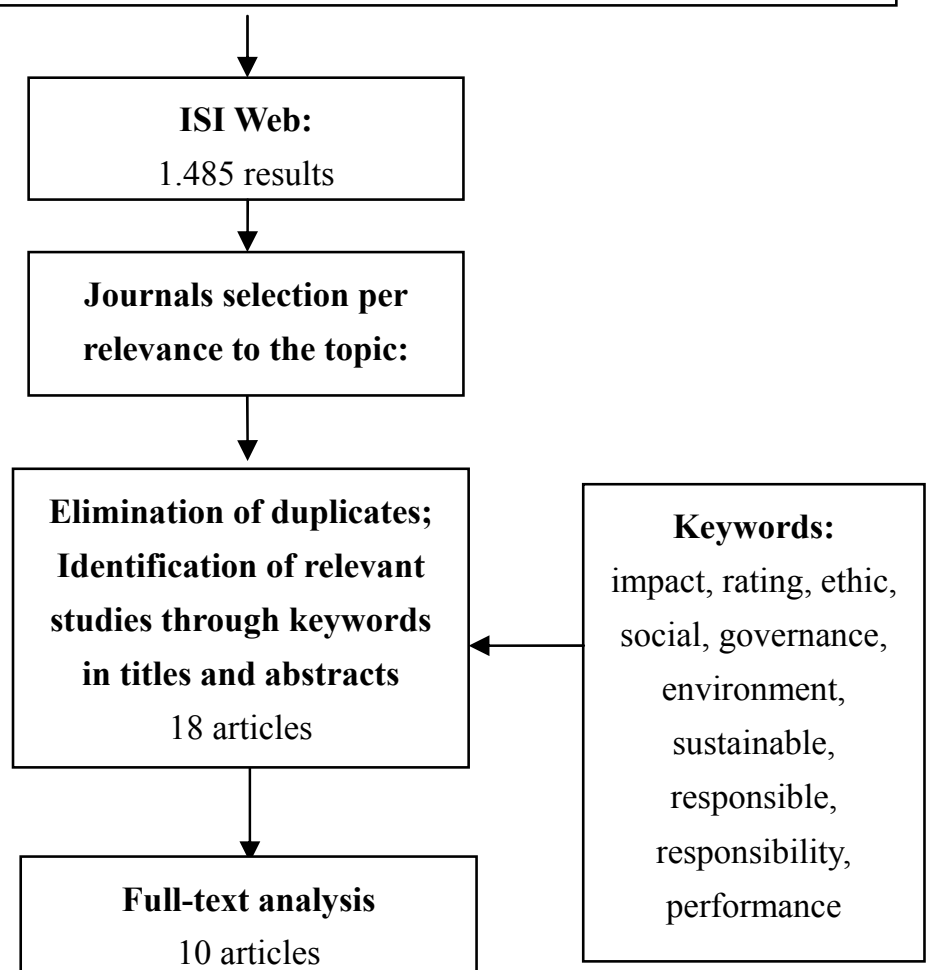

Figure 1. Literature review process from step 1 through step 3

Step 4 consisted in summarizing results as shown in Table 2, by reporting main statements by the authors on three aspects: behavioral and ethical issues in the decision-making process; financial perspective; sustainable asset management. Finally, step 5 consisted in interpreting and re-elaborating findings as discussed in the following section and as shown in Figures 2 and 3. 


\section{Results and Discussion}

A first point to be highlighted is the main concentration of publications after the 2007 crisis. This can be seen both after the first step and after the third step of the review. In fact, results showed a median year 2010 on the whole sample of articles (1.485) and a median year 2011 on the final selection (10).

To better focus on the critical issues of our analysis, we analyzed papers under three main drivers: behavioral and ethical issues in the decision-making process, financial perspective, and sustainable asset management. Table 2 identifies the main statements within each paper for each driver defined.

Table 2. Literature review-summary of the results

\begin{tabular}{|c|c|c|c|}
\hline Authors & $\begin{array}{c}\text { Behavioral and Ethical Issues in } \\
\text { Decision Making }\end{array}$ & Sustainable Asset Management & Financial Perspective \\
\hline $\begin{array}{l}\text { Choi and Gray } \\
(2008)\end{array}$ & $\begin{array}{l}\text { The corporation has a responsibility } \\
\text { to help solving social issues } \\
\text { (employment, pollution, safety, etc.). } \\
\text { Over time these issues have } \\
\text { expanded to include business ethics, } \\
\text { corporate governance, and } \\
\text { sustainable development. }\end{array}$ & $\begin{array}{l}\text { There is a need to adopt a triple bottom line } \\
\text { approach (economic, environmental, and } \\
\text { social) for contributing to the good of } \\
\text { society. }\end{array}$ & \\
\hline $\begin{array}{l}\text { Eberhardt-Toth } \\
\text { and Wasieleski } \\
(2013)\end{array}$ & $\begin{array}{l}\text { There is a need to understand what } \\
\text { motivates sustainable and ethical } \\
\text { behavior by examining the cognitive } \\
\text { and intrinsic motivating tendencies } \\
\text { of individuals. The purpose is to raise } \\
\text { awareness of individual managers } \\
\text { regarding the importance of adopting } \\
\text { sustainable initiatives so they are } \\
\text { motivated to integrate sustainable } \\
\text { practices into their strategic planning. }\end{array}$ & $\begin{array}{l}\text { Sustainable development implies a decision } \\
\text { based on a triple bottom line view that } \\
\text { involves the consideration of social, } \\
\text { environmental, and economic performance } \\
\text { of decisions. }\end{array}$ & $\begin{array}{l}\text { Chief Financial Officers } \\
\text { (CFOs) play an important role } \\
\text { in the formulation of a } \\
\text { sustainability strategy. } \\
\text { "Finance is the best placed } \\
\text { function to take the lead on } \\
\text { sustainability and manage } \\
\text { corporate performance in this } \\
\text { area" (authors citing Stilwell, } \\
\text { 2009) }\end{array}$ \\
\hline $\begin{array}{l}\text { Fatemi and } \\
\text { Fooladi (2013) }\end{array}$ & $\begin{array}{l}\text { The decision maker needs to } \\
\text { recognize, and account for, all costs } \\
\text { and benefits (economic, social, and } \\
\text { environmental) before adopting (or } \\
\text { rejecting) a project. }\end{array}$ & $\begin{array}{l}\text { It can be argued that non-adopting firms } \\
\text { (i.e., those following the traditional profit } \\
\text { maximization model) will experience a } \\
\text { negative demand shift as the detrimental } \\
\text { effects of inattention to social and } \\
\text { environmental issues become more broadly } \\
\text { recognized. }\end{array}$ & $\begin{array}{l}\text { The decision to introduce } \\
\text { social and environmental } \\
\text { constraints has the potential to } \\
\text { shift the demand curve such } \\
\text { that the new achievable } \\
\text { maximum would dominate the } \\
\text { old conception of profit } \\
\text { maximization. }\end{array}$ \\
\hline $\begin{array}{l}\text { Girerd-Potin, } \\
\text { Jimenez-Garces, } \\
\text { and Louvet. } \\
(2014)\end{array}$ & $\begin{array}{l}\text { It appears that before } 2008 \text { financial } \\
\text { investors focused their social } \\
\text { responsibility concerns on the way } \\
\text { firms managed their relationships } \\
\text { with their business stakeholders. } \\
\text { Recently, environmental and } \\
\text { community involvement have also } \\
\text { become risk factors in investors' } \\
\text { minds. }\end{array}$ & $\begin{array}{l}\text { A firm's behavior in the three ESG } \\
\text { dimensions appear not to be independent, } \\
\text { thus meaning that a firm's behavior is } \\
\text { driven by the ESG paradigm }\end{array}$ & $\begin{array}{l}\text { Firms that are not socially } \\
\text { responsible are seen as more } \\
\text { risky. As a result, investors } \\
\text { are likely to ask for additional } \\
\text { risk premiums when they } \\
\text { decide to hold non-socially } \\
\text { responsible stocks. Thus, } \\
\text { environment and social issues } \\
\text { have recently become risk } \\
\text { factors in investors' minds. }\end{array}$ \\
\hline $\begin{array}{l}\text { Hebb, Hamilton, } \\
\text { and Hachigian } \\
(2010)\end{array}$ & $\begin{array}{l}\text { ESG orientation to be incorporated } \\
\text { into the investment decision-making } \\
\text { process. }\end{array}$ & $\begin{array}{l}\text { Impact of sustainable assets and properties } \\
\text { on rents. }\end{array}$ & $\begin{array}{l}\text { Long term horizon more } \\
\text { deeply felt due to the } \\
\text { materiality of ESG issues. } \\
\text { ESG factors play a significant } \\
\text { role in both reputation risk } \\
\text { and share value over time. }\end{array}$ \\
\hline $\begin{array}{l}\text { Hoechstaedter and } \\
\text { Scheck (2015) }\end{array}$ & $\begin{array}{l}\text { Responsible investment should take } \\
\text { into account the integration of }\end{array}$ & & \\
\hline
\end{tabular}


environmental, social and

governance criteria into mainstream investment decision-making and ownership practices.

Fiduciaries have a duty to consider more actively the adoption of responsible investment strategies and must recognize that integrating ESG

Humprey, Lee, issues into investment and ownership and Shen (2012) processes is part of responsible investment, and is necessary to managing risk and evaluating opportunities for long-term investment.

Markets pay attention to corporate governance by rewarding good governance and punishing poor governance, which in turn is integral to CSR.

SRI needs a stronger ethical foundation to contribute more thoroughly to sustainability. Ownership, competition, and Richardson (2009) material gain are characteristics of the financial world which reduces nature to an expedient resource for short-term gain.

Because of the numerous possible Soppe (2004) games of economic agents, the behavioral approach does not reduce agency costs
From the investor's perspective, ESG analysis can be regarded as an additional tool to utilize in the asset valuation and risk assessment process. ESG analysis investigates factors that will determine a company's strengths and weaknesses, in much the same way as traditional financial (e.g. ratio) analysis does. However, the source of these strengths and weaknesses is material ESG opportunities and threats. Consequently, ESG analysis complements, rather than replaces, traditional financial analysis.

Financial institutions must be seen as endowed with public responsibilities and be governed by standards that protect natural and social systems for the long term.

Sustainable corporate finance, with the aim to create a policy of caring for future generations, encourages an approach to financial markets from which normative human and economic guidelines can be deducted.
It is argued that firms with better CSP have a relative business advantage that allows them to financially benefit from ESG opportunities and threats. However, for sustained abnormal returns to occur the market would need to systematically misprice the value of CSP.
Finance is a positive science in which rational behavior automatically optimizes efficiency.

By analyzing the results, two main categories may be identified: 1) papers highlighting the need to adopt socially responsible and sustainable paradigms and methods of asset pricing (Choi \& Gray, 2008; Fatemi \& Fooladi, 2013; Hoechstaedter and Scheck, 2015; Humprey et al., 2012; Neal and Cochran, 2008; Richardson, 2009; Soppe, 2004), and 2) papers demonstrating the positive impact of ESG ratings and the adoption of socially responsible and sustainable investor behavior on financial performances (Eberhardt-Toth \& Wasieleski, 2012; Girerd-Potin et al., 2014; Hebb et al., 2010).

The first aspect is highlighted by the authors under different points of view. Soppe (2004), for example, showed how finance has generally been considered a positive science in which rational behavior automatically optimizes efficiency. According to the author, in this view adopting solely a behavioral approach is not enough for reducing agency costs and information asymmetry, but is required a step more oriented to a sustainable approach in normative, human behavior and economic guidelines to be integrated with a policy of caring for future generations (Soppe, 2004).

According to Choi and Gray (2008), corporations have the responsibility to help in solving social and environmental issues, also including ethical, governance and sustainable matters. On this basis, the authors conclude for the need to adopt a triple bottom line approach (economic, environmental and social) for contributing to the good of society (Choi \& Gray, 2008).

As stated by Richardson (2009), one of the main reasons why ethical, social, and environmental questions are not addressed in the financial world, as in the investing decision-making process, may be found in the fact that 
actually they are not valued by the market: existing strategies in this model are unlikely to consider other non-financial factors in evaluating investments. Furthermore, Richardson (2009) underlined how without demonstrated financial advantage, "an investment analysis may advocate delaying or halting measures that mitigate pollution, especially in the absence of effective government regulation and stakeholder pressure" (p. 569).

Thus Richardson (2009), as well as Hoechstaedter and Scheck (2015), highlighted the necessity for a stronger ethical foundation to contribute more to sustainability: environmental, governance, and social criteria should be taken into account into mainstream investment decision-making processes in order to revolutionize the classic financial orientation to short term gain. In particular, Richardson (2009) identified that financial institutions must be endowed with public responsibilities and be governed by standards that protect natural and social systems for the long term.

Humprey et al. (2012) and Fatemi and Fooladi (2013) clearly stated that investors and decision makers have the duty to consider more actively the adoption of responsible investment strategies and to recognize and account for all costs and benefits (economic, social and environmental) before adopting (or rejecting) a project. In particular, Humprey et al. (2012) stated that integrating ESG issues into investment and ownership processes is part of responsible investment. Thus, from the investor's perspective, ESG analysis can be considered an additional tool to utilize, in addition to traditional financial analysis, in the asset valuation and risk assessment to determine a company's strengths and weaknesses.

Then, according to Fatemi and Fooladi (2013), ESG non-adopting firms (those following the traditional profit maximization model) would experience a negative demand shift as the detrimental effects of inattention to social and environmental issues will become more broadly recognized. This results in line with what highlighted by Neal and Cochrane (2008), about the fact that markets pay attention to socially responsible corporate governance by rewarding good governance and punishing poor governance.

Studies facing these themes under a quantitative approach, show the impact of ESG factors both on reputation risk and on share value over time (Girerd-Potin et al., 2014; Hebb et al., 2010). In particular, Girerd-Potin et al. (2014) evidence that after 2008, financial investors started considering environmental and community involvement as risk factors and that non-socially responsible firms are seen as more risky. Hebb et al. (2010), under a similar point of view, pointed out that long-term horizon is more deeply felt due to the materiality of ESG issues and that ESG orientation has to be incorporated into the investment decision-making process (as also evidenced by Humprey et al. (2012) and Fatemi and Fooladi (2013)).

In general, the need to radically change is clear in the theoretical and practical approach to finance, always taking into account social and environmental impacts (widening the concept of stakeholders) without forgetting the necessary and critical economic equilibrium.

Although there is still a scant production and attention to these themes, the results of this literature review confirm the hypothesis of a positive impact of social and responsible matters on corporate performances.

According to the analyzed studies, it could be assumed that an ethically and socially responsible corporate strategy may generate a virtuous circle (as shown in figure 2) involving the attention of investors (Fatemi and Fooladi, 2013; Humprey et al., 2012), thus convincing them to invest (Hebb et al., 2010) and, in turn, to let the firm receive positive returns on their financial performance (Girerd-Potin et al., 2014; Hebb et al., 2010).

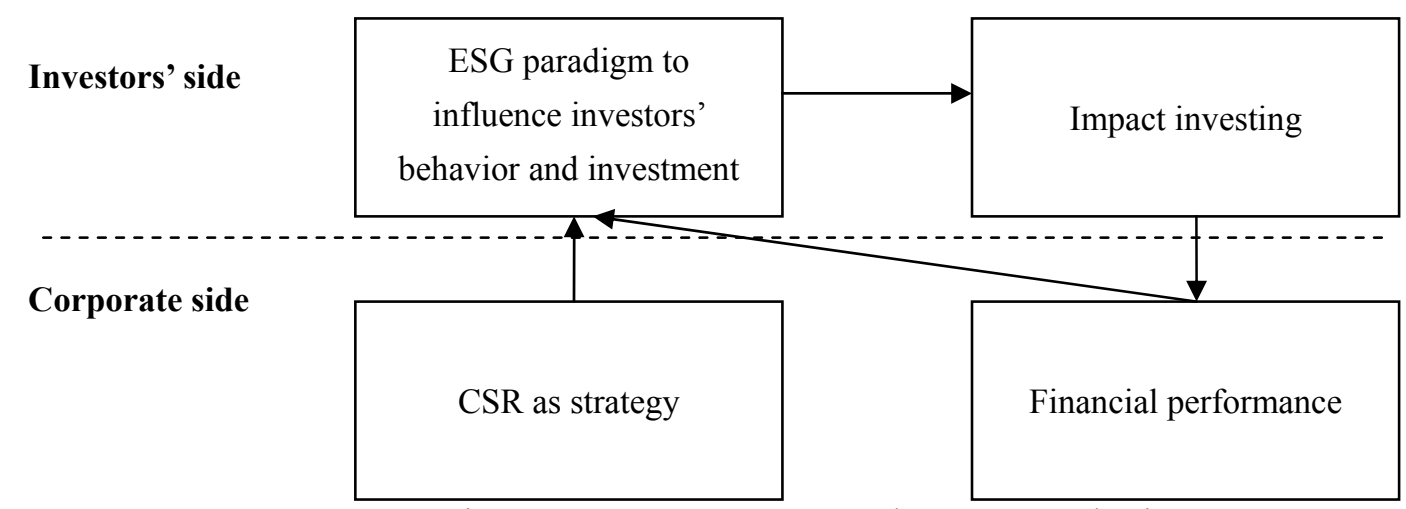

Figure 2. Corporate Strategy and Investors' Behavior. 
More in detail, a better firm capacity to be recognized by the market as ESG oriented, should facilitate investors' investment decision-making processes toward ethical and responsible investments; thus ESG oriented firms would be then awarded for their ESG approach obtaining a better financial performance through an abnormal return on the market (Girerd-Potin et al., 2014; Hebb et al., 2010).

As highlighted in Figure 2, the adoption of an ESG paradigm also influences firms' behavior and decision-making process, thus orienting them toward socially responsible investment (impact investing). Since its positive impact on financial performance, ESG orientation may represent a corporate strategy to perform in substitution to other less ethical strategies. On this basis, the following matrix (Figure 3) highlights four different corporate approaches, considering both ESG and non ESG strategies. The matrix shows two main dimensions: Corporate Strategy (ESG or non ESG) and Financial Performance (positive or negative market abnormal return).

\begin{tabular}{|c|c|c|c|}
\hline \multirow{4}{*}{$\begin{array}{l}\text { Financial } \\
\text { performance }\end{array}$} & \multirow[b]{2}{*}{ Positive abnormal return } & Short term & Long term \\
\hline & & Speculative approach & Impact investing (SRI) \\
\hline & \multirow[t]{3}{*}{$\begin{array}{l}\text { Negative abnormal } \\
\text { return }\end{array}$} & $\begin{array}{l}\text { Not efficient capital } \\
\text { allocation }\end{array}$ & $\begin{array}{lll}\begin{array}{l}\text { Green } \\
\text { washing }\end{array} & \& & \text { social } \\
\end{array}$ \\
\hline & & Not ESG & ESG \\
\hline & & Corporate Strategy & \\
\hline
\end{tabular}

Figure 3. Corporate behavior and ESG investments

A Corporate Strategy that is not ESG oriented, with a negative abnormal return, implies a non-efficient capital allocation regardless of sustainability issues, given that the management does not deploy the ESG paradigm, neither of which is a good investment policy.

A short term orientation, along with a non-ESG strategy and a positive abnormal return, results in a speculative approach by the firm, due to some information which the management does not share correctly with market.

The third approach, based on an ESG strategy and related to a negative abnormal return, represents a green and social washing approach followed by those companies which under evaluate investors' capability in gathering information.

Finally, an impact investment, representing a social responsible investment, is characterized by a long term oriented ESG strategy. This kind of investment has been the object of this study and has shown its positive impact over corporate financial performance by generating a positive abnormal return in addition to the market performance, which not all investors consider to include in their investments' evaluation.

\section{Conclusions}

This literature review has highlighted that some studies have already concentrated on the relevance of social issues before the 2007 crisis, but the real increase of academic production just took part in the aftermath of the crisis. Within this period, academic studies, both through quantitative (Eberhardt-Toth and Wasieleski, 2012; Girerd-Potin et al., 2014; Hebb et al., 2010) and qualitative methods (Choi and Gray, 2008; Fatemi and Fooladi, 2013; Hoechstaedter and Scheck, 2015; Humprey et al., 2012; Neal and Cochran, 2008; Richardson, 2009; Soppe, 2004), explored the impact and the need to adopt different parameters for measuring business performance, including the evaluation of social and ethical dimensions. In addition, in such an international context full of recent corporate scandals, ESG disclosure may have three main positive impacts for firms adopting them:

1. It shows corporate attention to sensitive issues such as social, ethics, and responsibility;

2. Then, it improves corporate capacity to be recognized, evaluated, and awarded by the market;

3. It helps in reducing information asymmetry by increasing available information for all investors, thus aiming to let markets become more efficient.

On this ground, if all companies would deploy an ESG strategy, the future market scenario will become more efficient on ESG versant and investors will not be awarded by their impact investing. Once the companies begin such virtuous emulation mechanisms, investors will be able to furtherly diversify their sustainable investment portfolios, given that they could buy more ESG securities on the stock exchange market. Thus, ESG Ratings will no longer make abnormal returns, but investors can use them for reducing the specific risk component of their 
investment portfolios.

Moreover, on one hand, investors can screen their portfolios with a larger number of ESG securities; on the other hand, a company can get a competitive advantage from this ESG investors' approach in the fundraising stage, thanks to an accurate ESG assessment able to attract a great amount of impact investments on financial markets. Therefore, our conclusion does not preclude investors from adding alpha in stock - picking skill, since they can buy (short) high ranked (low ranked) ESG firms when they are underpriced (overpriced) (Humphrey et al., 2012).

Finally, based on this analysis, a need is evidenced for a more ethically oriented education and for a substantial change to norms regulating markets and business behavior to sensitize investors and financial practitioners.

\section{Limits and Future Research Development}

This work suffers the typical limitations of literature reviews, which result from the selection of journals, the choice of number and type of keywords, and the resulting selection of studies, the choice of relevant outcomes and the interpretation, generalization and application of results.

Considering the increasing interest on CSR matter by corporations, future research could concentrate on the impact of ESG paradigm on financial performance of listed companies. The underlying question to this research topic could point out also whether investors are able to price the corporate social performance and if financial markets are efficient on ESG versant. Furtherly, it could be of interest verifying empirically what companies would be able to get a positive outlook by developing an ESG corporate strategy, as well as to investigate whether sustainability issues might represent reliable managerial tools for overcoming a crisis phase.

\section{References}

Akerlof, G. A. (1970). The Market for 'Lemons': Quality Uncertainty and the Market Mechanism. Quarterly Journal of Economics (The MIT Press), 84(3), 488-500. http://dx.doi.org/10.2307/1879431

Barlevy G., \& Veronesi P., (2000). Information Acquisition in Financial Markets. Review of Economic Studies, 67, 79-90. http://dx.doi.org/10.1111/1467-937X.00122

Choi, D. Y., \& Gray, E. R. (2008). Socially Responsible Entrepreneurs: What Do They Do To Create And Build Their Companies? Business Horizons, 51(4), 341-352. http://dx.doi.org/10.1016/j.bushor.2008.02.010

Corporate Excellence-Centre for Reputation Leadership. (2011. The functions and location of CSR in the company's organization chart: a step forward. Retrieved from http://www.corporateexcellence.org/index.php/eng/content/download/2460/33408/file/I06\%20The\%20funct ions $\% 20$ and $\% 20$ location $\% 20$ of $\% 20$ CSR $\% 20$ in $\% 20$ the $\% 20$ company $\%$ E2\%80\%99s $\% 20$ organization $\% 20 \mathrm{ch}$ art- $\% 20 \mathrm{a} \% 20$ step $\% 20$ forward.pdf

Devall, B., \& Sessions, G. (2001). Deep Ecology: Living as if Nature Mattered. Gibbs Smith, Layton.

Eberhardt-Toth, E., \& Wasieleski, D. M., (2013). A Cognitive Elaboration Model Of Sustainability Decision Making: Investigating Financial Managers' Orientation Toward Environmental Issues. Journal Of Business Ethics, 117(4), 735-751. http://dx.doi.org/10.1007/s10551-013-1715-1

Fatemi A., \& Fooladi I., (2013). Sustainable Finance: A New Paradigm. Global Finance Journal, 24, 101-113. http://dx.doi.org/10.1016/j.gfj.2013.07.006

Frankel R., \& Li X. (2004). Characteristics of a firm's information environment and the information asymmetry between insiders and outsiders. Journal of Accounting and Economics, 37, 229-259. http://dx.doi.org/10.1016/j.jacceco.2003.09.004

Girerd-Potin, I., Jimenez-Garces, S., \& Louvet, P. (2014). Which Dimensions Of Social Responsibility Concern Financial Investors?", Journal Of Business Ethics, 121(4), 559-576. http://dx.doi.org/10.1007/s10551-013-1731-1

Hebb, T., Hamilton, A., \& Hachigian, H. (2010). Responsible Property Investing In Canada: Factoring both Environmental And Social Impacts In The Canadian Real Estate Market. Journal of Business Ethics, 92, 99-115. http://dx.doi.org/10.1007/s10551-010-0636-5

Hoechstaedter, A. K., \& Scheck, B. (2015). What's in A Name: An Analysis Of Impact Investing Understandings By Academics And Practitioners. Journal of Business Ethics, 132(2), 449-475. http://dx.doi.org/10.1007/s10551-014-2327-0

Hopkins M. (2004). Corporate social responsibility: an issues paper. Working Paper n. 27, Policy Integration 
Department World Commission on the Social Dimension of Globalization International Labour Office Geneva. Retrieved from http://papers.ssrn.com/sol3/papers.cfm?abstract_id=908181

Humphrey, J., Lee, D., \& Shen Y. (2012). Does It Cost To Be Sustainable. Journal of Corporate Finance, 18, 626-639. http://dx.doi.org/10.1016/j.jcorpfin.2012.03.002

Kahneman, D. (2011). Thinking, Fast and Slow. New York: Farrar, Straus and Giroux.

Khan, K. S., Kunz, R., Kleijnen, J., \& Antes, G. (2003). Five steps to conducting a systematic review. Journal of the Royal Society of Medicine, 96(3), 118-121. http://dx.doi.org/PMC539417

Maignan, I., Ferrell, O. C., \& Ferrell, L. (2005). A Stakeholder Model for Implementing Social Responsibility in $\begin{array}{lllll}\text { Marketing. European Journal of } & \text { Marketing, }\end{array}$ http://dx.doi.org/10.1108/03090560510610662

Maon, F., Lindgreen, A., \& Swaen, V. (2009). Designing and Implementing Corporate Social Responsibility: An Integrative Framework Grounded in Theory and Practice. Journal of Business Ethics, 87, 71-89. http://dx.doi.org/10.1007/s10551-008-9804-2

Markowitz, H. (1952). Portfolio Selection. Journal of Finance, 7(1), 77-99. http://dx.doi.org/10.1111/j.1540-6261.1952.tb01525.x

Neal, R., \& Cochran, P. L. (2008). Corporate Social Responsibility, Corporate Governance, And Financial Performance: Lessons From Finance. Business Horizons, 51, 535-540. http://dx.doi.org/10.1016/j.bushor.2008.07.002

Panapanaan, V. M., Linnanen, L., Karvonen, M. M., \& Phan, V. T. (2003). Roadmapping Corporate Social Responsibility in Finnish Companies", Journal of Business Ethics, 44(2), 133-146, http://dx.doi.org/10.1023/A:1023391530903

Petrick, J. A. (2011). Sustainable Stakeholder Capitalism: A Moral Vision of Responsible Global Financial Risk Management. Journal of Business Ethics, 99, 93-109. http://dx.doi.org/10.1007/s10551-011-1157-6

Richardson, B. J. (2009). Keeping Ethical Investment Ethical: Regulatory Issues for Investing For Sustainability. Journal of Business Ethics, 87(4), 555-572. http://dx.doi.org/10.1007/s10551-008-9958-y

Simon, H. B. (1955). A Behavioral Model of Rational Choice. The Quarterly Journal of Economics, 69(1), 99-118. http://dx.doi.org/10.2307/1884852

Soppe, A. (2004). Sustainable Corporate Finance. Journal Of Business Ethics, 53(1-2), 213-224. http://dx.doi.org/10.1023/B:BUSI.0000039410.18373.12

Soskolne, C. (2007). Sustaining Life on Earth. Lexington Books, New York, NY.

Stachowicz-Stanusch, A., \& Mangia, G. (2016). Dark Sides of Business and Higher Education Management. New York, NY: Business Expert Press.

Stilwell, G. (2009). Sustainability reporting. Financial Management, 27-28.

\section{Copyrights}

Copyright for this article is retained by the author(s), with first publication rights granted to the journal.

This is an open-access article distributed under the terms and conditions of the Creative Commons Attribution license (http://creativecommons.org/licenses/by/4.0/). 